WITOLD GRACA

ORCID: 0000-0002-6226-7750

Uniwersytet Opolski

HENRYK SPUSTEK

ORCID: 0000-0001-7594-1866

Uniwersytet Opolski

\title{
Rola byłych funkcjonariuszy komunistycznych służb specjalnych w cywilnym wywiadzie i kontrwywiadzie Polski i Czech w latach 1989-2018
}

\section{Wprowadzenie}

W przestrzeni publicznej w Polsce funkcjonuje przekonanie, że czeskie cywilne służby specjalne, po zmianach ustrojowych w roku 1989, zostały gruntownie zmienione i oczyszczone $\mathrm{z}$ byłych funkcjonariuszy służb komunistycznych. W tym kontekście często używa się określenia, że w Czechach, w przeciwieństwie do Polski, nastąpiła tak zwana opcja zerowa, a czeskie służby zostały zbudowane od podstaw przez byłych opozycjonistów. Jednocześnie pojawiają się twierdzenia o „sprawiedliwej” karze w postaci odebrania przywilejów emerytalnych byłym pracownikom aparatu represji. W niektórych środowiskach politycznych w Polsce zakorzeniony jest też pogląd, jakoby Czesi zupełnie inaczej, w domyśle lepiej, sprawiedliwiej i skuteczniej, rozwiązali problem byłych funkcjonariuszy komunistycznej bezpieki.

Służby specjalne są trudnym obiektem badawczym, głównie ze względu na funkcjonowanie $\mathrm{w}$ ramach wyznaczonych przepisami o ochronie informacji niejawnych, które w praktyce uniemożliwiają poznanie kierunków pracy, metod, operacji czy też zmian kadrowych w tych organizacjach. Bariera informacyjna jest zasadniczym determinantem mającym wpływ na jakość badań oraz stawiane wnioski. Problemy w zakresie swobodnego dostępu do informacji mają szczegól- 
ny wpływ na jakość opisu, który jest niezbędnym składnikiem komparatystyki politycznej i badań porównawczych.

Wskazane problemy mają też zasadniczy wpływ na wybór metody badawczej. W politologii istnieją trzy metody badawcze dotyczące parametryzacji zmiennych: metoda eksperymentalna, metoda statystyczna i metoda porównawcza ${ }^{1}$. Trudno sobie wyobrazić zastosowanie badań eksperymentalnych wobec funkcjonariuszy służb specjalnych dwóch państw, metoda statystyczna z kolei wymaga szerokich prób, co w zakresie podjętego tematu byłoby nieadekwatne. Dlatego metoda porównawcza pozwala na przezwyciężenie trudności z eksperymentowaniem i jest alternatywnym rozwiązaniem metody statystycznej, gdy liczba jednostek obserwacji jest zbyt niska, aby możliwe było statystyczne opracowanie danych ${ }^{2}$.

Analiza porównawcza sytuacji byłych funkcjonariuszy komunistycznych służb specjalnych w latach 1989-2018 w Polsce i w Republice Czeskiej (do 31 grudnia 1992 roku Czechosłowacji) została przeprowadzona pod kątem przebiegu ich weryfikacji po roku 1989, udziału w budowaniu nowych, cywilnych służb specjalnych oraz ich sytuacji prawnej w związku z prowadzanymi w poszczególnych państwach zmianami emerytalnymi. Uzyskane wnioski dają podstawy do stwierdzenia, że początkowo podobne w sferze rozwiązań instytucjonalnych i przyjętych wartości systemy polityczne Polski i Republiki Czeskiej zmierzają w stronę różnych modeli.

\section{Działalność komisji weryfikacyjnych w Polsce i Czechosłowacji po roku 1989}

Komisje weryfikacyjne działające w Polsce i Czechach w roku 1990, których zadaniem była ocena przydatności funkcjonariuszy komunistycznych służb do pracy dla demokratycznego państwa, były inaczej skonstruowane w obu tych krajach. W ówczesnej Republice Czeskiej komisje składały się z przedstawicieli szerokiego spektrum sił politycznych łącznie z przedstawicielami Komunistycznej Partii Czechosłowacji i byłymi funkcjonariuszami komunistycznego Korpusu Bezpieczeństwa Narodowego, którzy zostali wydaleni ze służby z powodów politycznych po Praskiej Wiośnie. W Polsce charakter tych komisji był bardziej urzędniczy. Wyniki prac komisji w obu krajach obrazuje tabela 1.

${ }^{1}$ D. della Porta, Comparative Analisys: Case-oriented Versus Variable-oriented Research, [w:] Approaches and Methodologies in the Social Sciece. A Pluralist Perspective, red. D. della Porta, M. Keating, Cambrige 2008, s. 200; ibidem, s. 289; cyt. za: J. Bajer, Badania porównawcze w politologii. Zagadnienia metodologiczne, „Studia Politicae Universitatis Silensiensis” 8, 2012, http://bazhum.muzhp.pl/media//files/Studia_Politicae_Universitatis_Silesiensis/Studia_Politicae_ Universitatis_Silesiensis-r2012-t8/Studia_Politicae_Universitatis_Silesiensis-r2012-t8-s15-48/ Studia_Politicae_Universitatis_Silesiensis-r2012-t8-s15-48.pdf (dostęp: 23.11.2018).

$2^{-}$J. Bajer, op. cit. 
Tabela 1. Wyniki prac komisji weryfikacyjnych

\begin{tabular}{|l|c|c|}
\hline \multicolumn{1}{|c|}{ Kryterium } & Czechosłowacja & Polska \\
\hline liczba opiniowanych funkcjonariuszy & 7694 & 14500 \\
\hline $\begin{array}{l}\text { liczba przyjętych do nowych służb } \\
\text { specjalnych }\end{array}$ & 2308 & $\begin{array}{c}5522 \\
\text { (stan etatowy UOP } \\
\text { w roku) }\end{array}$ \\
\hline
\end{tabular}

Źródło: opracowanie własne.

\section{Byli funkcjonariusze komunistycznej StB w cywilnej służbie kontrwywiadu}

W styczniu 1990 roku został wydany rozkaz ministra spraw wewnętrznych CSSR, na mocy którego jako część MSW został powołany Urząd Federalnego Ministerstwa Spraw Wewnętrznych ds. Ochrony Konstytucji i Demokracji (Úřad Federálního Ministerstva Vnitra na Ochranu Ústavy a Demokracie - UOUD), późniejszy kontrwywiad cywilny. Dyrektorem nowo powstałej służby został w dniu 16 lutego 1990 roku Zdeněk Formánek, były funkcjonariusz Korpusu Bezpieczeństwa Narodowego, usunięty z jego szeregów po roku 1968. Wraz z nowym dyrektorem do służby wróciło wielu byłych funkcjonariuszy StB zwolnionych po Praskiej Wiośnie, którzy objęli stanowiska kierownicze. W połowie 1990 roku większość funkcjonariuszy UOUD tworzyli byli funkcjonariusze StB, którzy pozytywnie przeszli weryfikację — 2308 osób. Nowo przyjętych było jedynie czterdzieści osób. Osobną grupę stanowili byli funkcjonariusze StB, którzy w roku 1990 zostali przywróceni do służby po tym, jak w roku 1968 zostali z niej usunięci. Tę ostatnią grupę tworzyło trzydzieści osiem osób. Nowi funkcjonariusze, niezwiązani w przeszłości z StB, pełnili głównie funkcje kierownicze w centrali i w delegaturach wojewódzkich ${ }^{3}$.

W grudniu 1991 roku została powołana Federalna Służba Informacyjna Ministerstwa Spraw Wewnętrznych (Federální informační služba FMV — FIS). FIS w stosunku do UOUD została zredukowana z 3 tys. do 1,2 tys. etatów. Kolejna cywilna służba powstała na mocy ustawy nr 244/1991 o Federalnej Informacyjnej Służbie Bezpieczeństwa i wykorzystywaniu środków wywiadowczych (Zákon č. 244/1991 Sb) ${ }^{4}$. Powołanie nowej służby stało się kolejną okazją do weryfikacji funkcjonariuszy. W związku z rozpadem wspólnego, federalnego, państwa Czechów i Słowaków powstała Informacyjna Służba Bezpieczeństwa

3 Ibidem, s. 46; Zetocha K., Zpravodajské služby v nové demokracii: Česká republika. Disertační práce, Brno 2008 https://is.muni.cz/th/idfhl/Zetocha-Disertace_2008.pdf (dostęp: 23.10.2018).

4 Zákon č. 244/1991 Sb., Zákon o Federální bezpečnostní informační službě a o používání zpravodajských prostředků, https://www.zakonyprolidi.cz/cs/1991-244 (dostęp: 24.10.2018). 
Republiki Czeskiej (Zákon č. 527/1992 Sb.) ${ }^{5}$. Służba ta była jedynie swego rodzaju formą przejściową. W 1994 roku zostały uchwalone ustawy, które stały się podstawą działania służb specjalnych w Republice Czeskiej, w tym ustawa nr 154/1994 o Informacyjnej Służbie Bezpieczeństwa (Zákon č. 154/1994 Sb., Zákon o bezpečnostní informační službě) ${ }^{6}$. W roku 1995 byli funkcjonariusze StB stanowili 4\% wszystkich pracowników BIS, których było wówczas około sześciuset ${ }^{7}$.

\section{Byli funkcjonariusze komunistycznej StB w cywilnej służbie wywiadu}

Prowizoryczna służba wywiadowcza została powołana równocześnie z likwidacją Korpusu Bezpieczeństwa Narodowego jako Służba Wywiadowcza Federalnego Ministerstwa Spraw Wewnętrznych (Zpravodajská služba FMV). Jej pierwszym dyrektorem został Přemysl Holan, były funkcjonariusz StB usunięty ze służby po roku 1968.

W Głównym Zarządzie Wywiadu StB (I. správa FMV/SNB, Hlavní správa rozvědky) w roku 1989 pracowało 1,3 tys. osób. Do nowej służby została przyjęta połowa z nich. Po kolejnej reorganizacji i powołaniu w dniu 21 grudnia 1990 roku Urzędu ds. Kontaktów Zagranicznych i Informacji Federalnego Ministerstwa Spraw Wewnętrznych (Úřad pro zahraniční styky a informace Federálního Ministerstva vnitra - ÚZSI FMV ČR) ze służby odeszło około $80 \%$ byłych funkcjonariuszy $\mathrm{StB}^{8}$. Według informacji Instytutu Studiów Reżimów Totalitarnych w roku 2015 w Policji Czeskiej Republiki i w służbach specjalnych pracowało ponad tysiąc byłych funkcjonariuszy komunistycznej $\mathrm{StB}^{9}$.

5 Zákon č. 527/1992 Sb., Zákon České národní rady o Bezpečnostní informační službě České republiky, https://www.zakonyprolidi.cz/cs/1992-527 (dostęp: 24.10.2018).

6 Zákon č. 154/1994 Sb., Zákon o bezpečnostní informační službě, http://www.epi.sk/zzcr/1994154 (dostęp: 24.10.2018).

7 J. Spurný, BIS a ti druzi, „Respekt” 13.02.1995, https://www.respekt.cz/tydenik/1995/7/bisa-ti-druzi (dostęp: 24.10.2018).

8 T. Ryza, Srovnání vývoje zpravodajských služeb v ČR a SR po roce 1989, Praha 2012, https://is.cuni.cz/webapps/zzp/detail/109572/ (dostęp: 1.11.2018).

9 J. Skalický, Před 25 lety zanikla StB, nejmocnější složka komunistického reżimu, iRozhlas 2015, https://www.irozhlas.cz/zpravy-domov/pred-25-lety-zanikla-stb-nejmocnejsi-slozka-komunistickeho-rezimu_201502010249_krohackova?print=1 (dostęp: 1.11.2018). 


\section{Zmiany w przepisach emerytalnych zmierzające do pozbawienia byłych funkcjonariuszy komunistycznych służb specjalnych przywilejów emerytalnych w Czechach i w Polsce}

W dniu 9 maja 1990 roku czechosłowackie Zgromadzenie Federalne uchwaliło ustawę 169/1990 o komisjach obywatelskich. Na podstawie treści tej ustawy wszyscy funkcjonariusze, którzy służyli w Korpusie Bezpieczeństwa Narodowego w okresie od 1 stycznia 1971 do 10 maja 1990 roku, z dniem 1 września 1990 roku utracili dodatek za służbę (w praktyce emerytura mundurowa), o ile na ich wniosek odpowiednie komisje obywatelskie nie zdecydowały inaczej.

Kolejną regulacją w tym zakresie była wprowadzona 8 lutego 1995 roku ustawa nr 33/1995 $\mathrm{Sb}^{10}$. Zgodnie z ustawą do dodatku za wysługę dla funkcjonariuszy Federalnej Informacyjnej Służby Bezpieczeństwa (Federální bezpečnostní informační služba - FBIS) nie wliczano okresów służby jako członka Korpusu Bezpieczeństwa Narodowego w ramach StB, jeśli dana osoba pracowała na odcinku kontrwywiadowczym lub wywiadowczym, w charakterze śledczego oraz pełniła funkcję naczelnika wydziału bądź wyższą. Ustawa ta została przyjęta głosami prawicowej Obywatelskiej Partii Demokratycznej (cz. Občanská demokratická strana lub ODS), z ramienia której premierem w latach 1992-1998 był Václav Klaus. Ustawa nr 33/1995 Sb została w dniu 3 kwietnia 1995 roku skierowana przez grupę czterdziestu dwu posłów Izby Poselskiej Parlamentu Republiki Czeskiej do Trybunału Konstytucyjnego z wnioskiem o uchylenie. Grupie posłów przewodził Jaroslav Ortman związany z Komunistyczną Partią Czech i Moraw (KSCM), a później z Blokiem Lewicowym (cz. Levý blok). Skarga ta została wyrokiem trybunału z dnia 28 lutego 1996 roku odrzucona ${ }^{11}$.

Próby pozbawienia byłych funkcjonariuszy StB dodatku za wysługę powtarzały się kilkakrotnie. W roku 2011 w trakcie kadencji premiera Petra Nečasa, który był szefem rządu tworzonego przez koalicję partii centroprawicowych, został przygotowany projekt ustawy pozbawiającej wszystkich byłych funkcjonariuszy StB dodatków za wysługę. Środki, które państwo miało zaoszczędzić w ten sposób, miały zasilić fundusz przeznaczony na wypłaty odszkodowań dla byłych więźniów politycznych. Jednak przepisy te zostały wycofane. Krytycy projektu

10 Zákon č. 33/1995 Sb., Zákon, kterým se mění a doplňuje zákon České národní rady č. 186/1992 Sb., o služebním poměru příslušníků Policie České republiky, ve znění pozdějších předpisů, a zákon č. 100/1970 Sb., o služebním poměru příslušníků Sboru národní bezpečnosti, ve znění pozdějších předpisů, https://www.zakonyprolidi.cz/cs/1995-33 (dostęp: 1.11.2018).

11 Nález ÚS ČR o zamítnutí návrhu na zrušení č. 34/1995, 107/1996 Sb., https://www.zakonyprolidi.cz/cs/1996-107 (dostęp: 4.11.2018). 
wskazywali na przyjęcie przez autorów zasady winy zbiorowej, która nie została zastosowana nawet $\mathrm{w}$ denazyfikacji Niemiec ${ }^{12}$.

W Polsce nieco podobne do czeskich rozwiązania zostały przyjęte dopiero w roku 2009, kiedy Sejm w ustawie z dnia 23 stycznia 2009 roku osobom pełniącym służbę $\mathrm{w}$ organach bezpieczeństwa państwa, pozostającym w służbie przed 2 stycznia 1999 roku, obniżył wymiar emerytury na $0,7 \%$ za każdy rok służby w tych organach w latach 1944-1990. Nowe przepisy zostały przyjęte głosami posłów Platformy Obywatelskiej oraz Prawa i Sprawiedliwości. Regulacja ta objęła 41689 osób. Ustawa została zaskarżona do Trybunału Konstytucyjnego, który w wyroku z dnia 24 lutego 2010 roku (sygn. akt K 6/09) orzekł, że obniżenie wyższych emerytur oficerom byłej Służby Bezpieczeństwa jest zgodne z konstytucją.

Kolejna nowelizacja zmieniająca ustawę o zaopatrzeniu emerytalnym funkcjonariuszy służb mundurowych została przyjęta przez Sejm 30 grudnia 2016 roku głosami Prawa i Sprawiedliwości. Zgodnie z tą ustawą funkcjonariusze byłej SB, którzy pozytywnie przeszli proces weryfikacji i następnie przez wiele lat pracowali w służbach demokratycznego państwa, kończąc służbę w szeregach Agencji Bezpieczeństwa Wewnętrznego i Agencji Wywiadu, zostali pozbawieni prawa do emerytur mundurowych, nawet wówczas gdy prawo to wynikało z okresów służby w ABW lub AW. Ich emerytury zostały obniżone do wysokości przeciętnej emerytury wypłacanej przez Zakład Ubezpieczeń Społecznych.

\section{Byli funkcjonariusze komunistycznej Służby Bezpieczeństwa}

\section{w cywilnej służbie kontrwywiadu i wywiadu w Polsce}

W przeciwieństwie do Czech w Polsce, zgodnie z zarządzeniem Prezesa Rady Ministrów określającym zadania oraz strukturę organizacyjną UOP ${ }^{13}$, w ramach urzędu działał Zarząd Wywiadu i Zarząd Kontrwywiadu. Podstawę kadrową nowej służby stanowili pozytywnie zweryfikowani funkcjonariusze Służby Bezpieczeństwa. Dyrektorami większości zarządów i biur zostali mianowani byli oficerowie $\mathrm{SB}^{14}$. W zasadzie jedynym wyjątkiem w roku 1990 było nowo powo-

12 R. Zemanová-Kopecká, Bývali agenti StB, bud'te v klidu. Odbojáři vám na důchody nesáhnou, ParlamentníListy.cz, https://www.parlamentnilisty.cz/zpravy/Byvali-agenti-StB-budte-v-klidu-Odbojari-vam-na-duchody-nesahnou-210219 (dostęp: 1.11.2018).

13 Zarządzenie nr 39 Prezesa Rady Ministrów z dnia 4 lipca 1990 roku w sprawie szczegółowego określenia zadań oraz struktury organizacyjnej Urzędu Ochrony Państwa, [w:] Historyczno-prawna analiza struktur organów bezpieczeństwa państwa w Polsce Ludowej (1944-1990). Zbiór studiów, red. A. Jusupović, R. Leśkiewicz, Warszawa 2013, s. 305-307.

14 Rozkaz personalny nr 01 z dnia 12 lipca 1990, [w:] K. Kozłowski, Rewolucja po polsku, „Przegląd Bezpieczeństwa Wewnętrznego. Wydanie specjalne” 2010, s. 16-17, https://www.abw. gov.pl/pl/pbw/publikacje/przeglad-bezpieczenstw-1/569,Przeglad-Bezpieczenstwa-WewnetrznegoWYDANIE-SPECJALNE.html (dostęp: 5.11.2018). 
łane Biuro Analiz i Informacji. W październiku 1990 roku biuro zatrudniało około osiemdziesięciu osób (stan etatowy określono na 125 pracowników). Połowę kadry stanowili funkcjonariusze nowo przyjęci do służby ${ }^{15}$.

Najważniejsze zmiany kadrowe w UOP nastąpiły w roku 1999, wówczas rząd Jerzego Buzka przeprowadził reformę administracyjną kraju, która spowodowała zmiany organizacyjne w służbach. W latach 1998-2001 z Urzędu Ochrony Państwa odeszło około 1,4 tys. funkcjonariuszy, głównie wywodzących się z byłej Służby Bezpieczeństwa ${ }^{16}$.

Urząd Ochrony Państwa został zlikwidowany ustawą z dnia 24 maja 2002 roku, która powoływała do istnienia Agencję Bezpieczeństwa Wewnętrznego i Agencję Wywiadu jako dwie odrębne służby - kontrwywiadowczą i wywiadowczą ${ }^{17}$. Według danych z 2009 roku Agencja Bezpieczeństwa Wewnętrznego liczyła 5490 etatów, a Agencja Wywiadu 1034 etaty ${ }^{18}$. W roku 2016 w ABW służyło około trzystu funkcjonariuszy wywodzących się z dawnej Służby Bezpieczeństwa, w AW kilkudziesięciu. W tym samym roku z ABW i AW odeszło łącznie 172 funkcjonariuszy zaczynających służbę w SB. W lutym 2018 roku W związku z podpisaniem przez premiera nowego statutu Agencji Bezpieczeństwa Wewnętrznego, na podstawie którego zlikwidowano dziesięć delegatur terenowych agencji ${ }^{19}$, w ABW zostały prawdopodobnie przeprowadzone kolejne zmiany kadrowe zmierzające do całkowitego wyeliminowania z jej szeregów byłych funkcjonariuszy służb specjalnych PRL. Zmiany te zapowiadał minister koordynator służb specjalnych Mariusz Kamiński już z końcem 2017 roku, w budżecie ABW na odprawy w roku 2018 przewidziano środki w wysokości $50 \mathrm{mln}$ złotych $^{20}$.

15 K. Miodowicz, Wszystko zaczęło się w Krakowie, „Przegląd Bezpieczeństwa Wewnętrznego. Wydanie specjalne" 2010, s. 13, https://www.abw.gov.pl/pl/pbw/publikacje/przeglad-bezpieczenstw1/569,Przeglad-Bezpieczenstwa-Wewnetrznego-WYDANIE-SPECJALNE.html (dostęp: 5.11.2018).

16 Rozporządzenie Prezesa Rady Ministrów z dnia 19 marca 1999 roku w sprawie zakresu działania i właściwości terytorialnej delegatur Urzędu Ochrony Państwa (Dz.U. z 1999 r. Nr 26, poz. 232).

17 Ustawa z dnia 24 maja 2002 roku o Agencji Bezpieczeństwa Wewnętrznego oraz Agencji Wywiadu (Dz.U. z 2002 r. Nr 74, poz. 676), http://prawo.sejm.gov.pl/isap.nsf/DocDetails.xsp?id=WDU20020740676 (dostęp: 6.11.2018).

18 M. Henzler, Etaty i budżety stużb specjalnych, „Polityka” 26.10.2009, https://www.polity$\mathrm{ka} \cdot \mathrm{pl} /$ tygodnikpolityka/kraj/1500287,1,etaty-i-budzety-sluzb-specjalnych.read?page=226\&moduleId=4677 (dostęp: 6.11.2018).

19 Obwieszczenie Prezesa Rady Ministrów z dnia 26 lutego 2018 roku w sprawie ogłoszenia jednolitego tekstu zarządzenia Prezesa Rady Ministrów w sprawie nadania statutu Agencji Bezpieczeństwa Wewnętrznego (M.P. poz. 279 z 13 marca 2018 r.), http://prawo.sejm.gov.pl/isap.nsf/ download.xsp/WMP20180000279/O/M20180279.pdf (dostęp: 7.11.2018).

20 Reorganizacja slużb specjalnych. Spóźniona dekomunizacja w ABW ma wreszcie nastąić?, PAP/MoRo, Wnet.fm, 28.09.2017, https://wnet.fm/2017/09/28/reorganizacja-sluzb-specjalnych-spozniona-dekomunizacja-abw-wreszcie-nastapic/ (dostęp: 7.11.2018). 


\section{System emerytalny służb mundurowych w Polsce i w Czechach}

System emerytalny służb mundurowych w Czechach jest skonstruowany zupełnie inaczej niż w Polsce (tab. 2). Emerytura mundurowa w Czechach w rzeczywistości nie jest emeryturą $\mathrm{w}$ polskim rozumieniu tego słowa, ale rodzajem zasiłku socjalnego związanego ze stażem w służbie (výsluhový př́spěvek, výsluha, výsluhová renta $)^{21}$. Jeśli dojdzie do sytuacji, że były funkcjonariusz służb mundurowych uprawniony do otrzymywania zasiłku wynikającego z wysługi lat uzyska prawo do emerytury (starobni dicchod) lub renty inwalidzkiej (invalidní díchod), wysokość świadczenia przelicza się indywidualnie. Zasiłek nie zostanie zabrany tylko wówczas, jeśli jest wyższy od emerytury.

Tabela 2. Porównanie systemów emerytalnych służb mundurowych w Polsce i w Czechach

\begin{tabular}{|l|l|l|}
\cline { 2 - 3 } \multicolumn{1}{c|}{} & System emerytalny w Czechach & System emerytalny w Polsce \\
\hline $\begin{array}{l}\text { staż służby uprawniający } \\
\text { do świadczenia }\end{array}$ & 15 lat & $\begin{array}{l}\text { 25 lat służby i ukończony } 55 \text { rok } \\
\text { życia }\end{array}$ \\
\hline wysokość świadczenia & $\begin{array}{l}20 \% \text { średniego miesięcznego } \\
\text { przychodu brutto }\end{array}$ & $\begin{array}{l}60 \% \text { średniego uposażenia funk- } \\
\text { cjonariusza należnego przez okres } \\
\text { kolejnych 10 lat kalendarzowych, } \\
\text { wybranych przez funkcjonariusza }\end{array}$ \\
\hline
\end{tabular}

Źródło: opracowanie własne.

\section{Podsumowanie}

$\mathrm{Na}$ podstawie przeprowadzonej analizy porównawczej roli, jaką odegrali byli funkcjonariusze komunistycznych służb specjalnych w cywilnym wywiadzie i kontrwywiadzie Polski i Czech w latach 1989-2018, można postawić następujące wnioski.

Nowe służby demokratycznego państwa w Czechach w roku 1990 zostały zbudowane przez dwie grupy byłych funkcjonariuszy komunistycznego Korpusu Bezpieczeństwa Narodowego i StB, wydalonych ze służby po Praskiej Wiośnie oraz tych, którzy pozytywnie przeszli weryfikację. Najwyższe stanowiska w nowych służbach specjalnych utworzonych po roku 1990 w Czechach objęli byli funkcjonariusze StB związani ze stowarzyszeniem Klub na Rzecz Socjalistycznej Przebudowy „Odnowa”, który tworzyli dawni działacze Komunistycznej Partii Czechosłowacji usunięci z jej szeregów po wkroczeniu do Czechosłowacji wojsk Układu Warszawskiego. Środowisko to wchodziło w skład Forum Obywatelskie-

${ }^{21}$ L. Mečírová, Náleži výsluhová renta i osobám ve starobním důchodu?, Finance.cz, https:// www.finance.cz/508953-vysluhova-renta-starobni-duchod/ (dostęp: 25.10.2018). 
go. Do nowej, cywilnej służby bezpieczeństwa w roku 1990 przyjęto 2308 byłych funkcjonariuszy StB. W roku 1990 grupa osób przyjętych do służby w cywilnym kontrwywiadzie, które wywodziły się z opozycji demokratycznej, liczyła czterdzieści osób. Podobnie wyglądało to w Polsce - w ramach Urzędu Ochrony Państwa, który miał 5522 etaty, grupa niewywodząca się ze Służby Bezpieczeństwa liczyła około czterdziestu-pięćdziesięciu osób. Trudno więc mówić o „opcji zerowej” w czechosłowackim, a później w czeskim kontrwywiadzie cywilnym. Sytuację kadrową w nowych służbach w Czechach i w Polsce przedstawiono na rysunku 1.

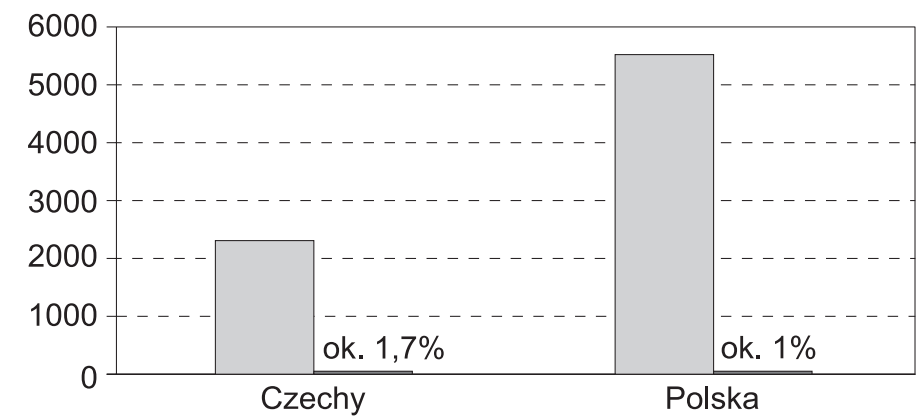

$\square$ liczba funkcjonariuszy wywodzących się ze służb komunistycznych

liczba funkcjonariuszy spoza byłych służb komunistycznych

Rys. 1. Sytuacja kadrowa w nowych służbach w Czechach i w Polsce w roku 1990

Źródło: opracowanie własne.

Inaczej wyglądała sytuacja $\mathrm{w}$ czechosłowackim wywiadzie - w wyniku reorganizacji w grudniu 1990 roku odeszło około 80\% byłych funkcjonariuszy StB. W tym przypadku można postawić tezę o przeprowadzeniu tak zwanej opcji zerowej.

Osoby wywodzące się z komunistycznej StB były stopniowo usuwane ze służb specjalnych w Czechach w rytmie kolejnych reorganizacji prowadzonych w latach 1990-1994. Największa taka reorganizacja odbyła się w grudniu 1991 roku. Ostatecznie po rozpadzie Czechosłowacji i powołaniu w roku 1994 Informacyjnej Służby Bezpieczeństwa (BIS) w służbie, według danych na rok 1995, pozostawało około $4 \%$ byłych funkcjonariuszy StB. Sama BIS liczyła wówczas około sześciuset pracowników. Według informacji czeskiego Instytutu Reżimów Totalitarnych w roku 2015 w Policji Republiki Czeskiej i służbach specjalnych pracowało jeszcze ponad tysiąc byłych funkcjonariuszy StB. Można stwierdzić, że funkcjonariusze komunistycznych służb specjalnych w omawianym okresie nie zostali w pełni usunięci ze służb.

W Polsce proces usuwania byłych funkcjonariuszy Służby Bezpieczeństwa ze struktur cywilnego wywiadu i kontrwywiadu również odbywał się w rytmie kolejnych reorganizacji. Największa fala odejść miała miejsce w latach 1998-2001, 
kiedy z Urzędu Ochrony Państwa odeszło około 1,4 tys. osób wywodzących się ze Służby Bezpieczeństwa. W roku 2002 powołano do życia Agencję Bezpieczeństwa Wewnętrznego (ABW), która liczyła 5490 etatów i Agencję Wywiadu (AW) dysponującą 1034 etatami. Byli funkcjonariusze SB w roku 2016 w ABW stanowili grupę liczącą około trzystu osób, natomiast w AW kilkadziesiąt osób. Sytuację tę przedstawiono na rysunku 2.

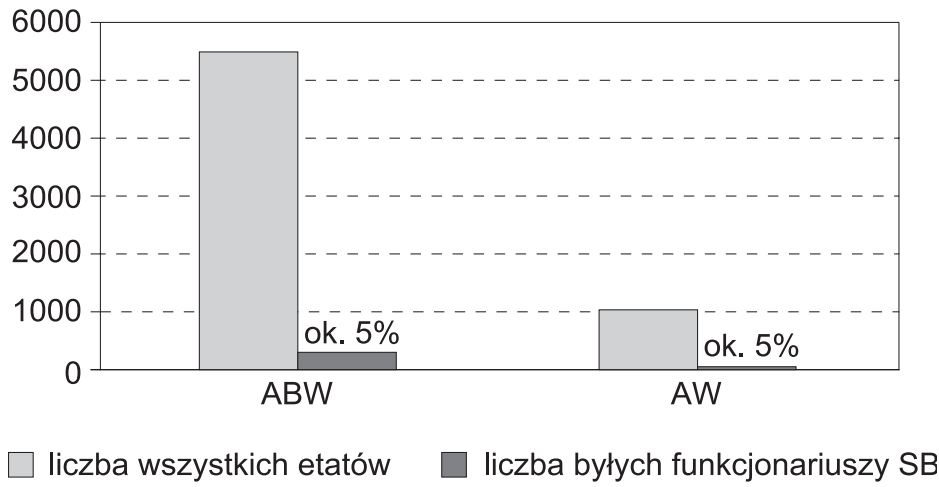

Rys. 2. Liczba byłych funkcjonariuszy SB pozostających w służbie w Polsce w 2016 roku Źródło: opracowanie własne.

Wszyscy byli funkcjonariusze komunistycznych służb specjalnych w Czechach, którzy służyli w Korpusie Bezpieczeństwa Narodowego od 1 stycznia 1971 roku do 10 maja 1990 roku, ze służby zostali zwolnieni w roku 1990, w wyniku weryfikacji, jak też ci, którzy sami się zwolnili, zostali pozbawieni tak zwanego dodatku za służbę. Również pozytywnie zweryfikowanych pracowników StB, przyjętych do nowych służb, pozbawiono w roku 1995 dodatku za wysługę, za okres służby w Korpusie Bezpieczeństwa Narodowego. Jednak, co bardzo ważne, dotyczyło to nie wszystkich byłych funkcjonariuszy StB, lecz ściśle określonej grupy, do której należeli: pracownicy komunistycznego kontrwywiadu, wywia$\mathrm{du}$, pionu śledczego oraz osoby pełniące funkcje naczelnika wydziału lub wyższą. Przepisy te zostały zaskarżone do Trybunału Konstytucyjnego, który jednak skargę oddalił. W kolejnych latach w czeskiej przestrzeni publicznej pojawiały się pomysły, aby wprowadzić ustawę, która odbierałaby prawo do dodatku za wysługę wszystkim byłym funkcjonariuszom StB, jednak nie doczekały się one realizacji. Zmiany w prawie zmierzające do pozbawienia byłych funkcjonariuszy StB uprawnień finansowych były forsowane przez czeską prawicę. Czesi nie odebrali byłym funkcjonariuszom StB prawa do dodatku za wysługę, wynikającego ze służby w formacjach mundurowych demokratycznego państwa.

W Polsce zostały wprowadzone dwie ustawy tak zwane dezubekizacyjne. Pierwsza z nich w roku 2009 zmniejszyła wymiar emerytur byłych funkcjonariuszy Służby Bezpieczeństwa do 0,7\% za każdy rok służby w organach bezpie- 
czeństwa państwa w latach 1944-1990. Skarga w tej sprawie została oddalona przez Trybunał Konstytucyjny w roku 2010. Druga ustawa, przyjęta w roku 2016, w praktyce pozbawiła byłych funkcjonariuszy Służby Bezpieczeństwa uprawnień do emerytur mundurowych, odbierając im także prawo do emerytur wypracowanych w ramach służb specjalnych demokratycznego państwa. Zmiany w przepisach odbierające byłym funkcjonariuszom SB uprawnienia emerytalne również w Polsce zostały przyjęte głosami prawicy.

Nie bez znaczenia dla porównania sytuacji byłych funkcjonariuszy komunistycznych służb specjalnych w Polsce i Czechach jest fakt, że system emerytalny służb mundurowych w Czechach działa na zupełnie innych zasadach niż w Polsce. W Republice Czeskiej tak zwany dodatek za wysługę, do którego funkcjonariusz zyskuje prawo po piętnastu latach służby, stanowi tylko $20 \%$ średniego uposażenia brutto i jest raczej pomyślany jako rodzaj zasiłku socjalnego. Głównym zadaniem tego zasiłku jest swoista rekompensata dla funkcjonariusza za to, że przez dużą część życia zawodowego zdobywał umiejętności, które raczej nie są przydatne na cywilnym rynku pracy. Nie jest to emerytura mundurowa w polskim rozumieniu tego pojęcia.

Podsumowując, można stwierdzić, że proces usuwania byłych funkcjonariuszy komunistycznych służb specjalnych ze struktur służb demokratycznego państwa w latach 1990-2018 przebiegał w obu krajach podobnie. Teza o przeprowadzeniu w Czechach opcji zerowej w służbach nie ma oparcia w faktach. Także istniejące w polskiej przestrzeni publicznej przekonanie, że Czesi wprowadzili jakieś radykalne rozwiązania prawne, których celem było swoiste wymierzenie sprawiedliwości pracownikom komunistycznego aparatu przemocy, nie znajduje potwierdzenia. Może to wynikać z różnic w systemie politycznym między Polską a Czechami, w których partie lewicowe, to znaczy czeska socjaldemokracja i partia komunistyczna, po roku 1989 były wciąż silne, jak też z przestrzegania zasad demokratycznego państwa prawa. Dążenia czeskiej prawicy do zniesienia przywilejów emerytalnych części byłych funkcjonariuszy StB, którzy je utrzymali po roku 1995, nie doczekały się realizacji głównie ze względu na obawy przed negatywnym stanowiskiem Trybunału Konstytucyjnego.

\section{Bibliografia}

\section{Materiały i dokumenty (akty prawa, traktaty, materiały konferencyjne, seminaryjne)}

Dz.Urz. MSW z 1990 r. Nr 2, poz. 10.

Langoš J., Odpowiedź ministra spraw wewnętrznych CSFR inż. Jana Langoša na interpelację poselską posła Izby Narodów Vladimira Mikule, http://www.psp.cz/eknih/1990fs/tisky/t0352_00. htm (dostęp: 23.10.2018).

Monitor Polski z 1990 r. Nr 20, poz. 159. 
Nález ÚS ČR o zamítnutí návrhu na zrušení č. 34/1995, 107/1996 Sb, https://www.zakonyprolidi. cz/cs/1996-107 (dostęp: 4.11.2018).

Obwieszczenie Prezesa Rady Ministrów z dnia 26 lutego 2018 roku w sprawie ogłoszenia jednolitego tekstu zarządzenia Prezesa Rady Ministrów w sprawie nadania statutu Agencji Bezpieczeństwa Wewnętrznego (M.P. poz. 279 z 13 marca 2018 r.), http://prawo.sejm.gov.pl/isap.nsf/ download.xsp/WMP20180000279/O/M20180279.pdf (dostęp: 7.11.2018).

Rozkaz ministra vnitra ČSSR č. 21 „Zřízení prověrkové komise federálního ministerstva vnitra“ z 7 lutego 1990 roku https://www.ustrcr.cz/data/pdf/rozkazy/rfmv90-92/21-90.pdf (dostęp: 23.10.2018).

Rozkaz ministra vnitra ČSSR č. 22 „Zásady spolupráce náčelníkủ útvarů v oboru působnosti federálního ministerstva vnitra s občanskými komisemi“" z 7 lutego 1990 roku, https://www.ustrcr. cz/data/pdf/rozkazy/rfmv90-92/22-90.pdf (dostęp: 23.10.2018).

Rozkaz personalny nr 01 z dnia 12 lipca 1990 roku, [w:] K. Kozłowski, Rewolucja po polsku, „Przegląd Bezpieczeństwa Wewnętrznego. Wydanie specjalne” 2010, https://www.abw.gov. $\mathrm{pl} / \mathrm{pl} / \mathrm{pbw} /$ publikacje/przeglad-bezpieczenstw-1/569,Przeglad-Bezpieczenstwa-Wewnetrzneg o-WYDANIE-SPECJALNE.html (dostęp: 5.11.2018).

Rozporządzenie Prezesa Rady Ministrów z dnia 19 marca 1999 roku w sprawie zakresu działania i właściwości terytorialnej delegatur Urzędu Ochrony Państwa (Dz.U. z 1999 r. Nr 26, poz. 232).

Ustawa $\mathrm{z}$ dnia 16 grudnia 2016 roku o zmianie ustawy o zaopatrzeniu emerytalnym funkcjonariuszy Policji, Agencji Bezpieczeństwa Wewnętrznego, Agencji Wywiadu, Służby Kontrwywiadu Wojskowego, Służby Wywiadu Wojskowego, Centralnego Biura Antykorupcyjnego, Straży Granicznej, Biura Ochrony Rządu, Państwowej Straży Pożarnej i Służby Więziennej oraz ich rodzin (Dz.U. z 2006 r. poz. 2270), http://prawo.sejm.gov.pl/isap.nsf/DocDetails.xsp?id=WDU20160002270 (dostęp: 7.11.2018).

Ustawa z dnia 23 stycznia 2009 roku o zmianie ustawy o zaopatrzeniu emerytalnym żołnierzy zawodowych oraz ich rodzin oraz ustawy o zaopatrzeniu emerytalnym funkcjonariuszy Policji, Agencji Bezpieczeństwa Wewnętrznego, Agencji Wywiadu, Służby Kontrwywiadu Wojskowego, Centralnego Biura Antykorupcyjnego, Straży Granicznej, Biura Ochrony Rządu, Państwowej Straży Pożarnej i Służby Więziennej oraz ich rodzin (Dz.U. z 2009 r. Nr 24, poz. 145), http://prawo.sejm.gov.pl/isap.nsf/DocDetails.xsp?id=WDU20090240145 (dostęp: 6.11.2018).

Ustawa z dnia 24 maja 2002 roku o Agencji Bezpieczeństwa Wewnętrznego oraz Agencji Wywiadu (Dz.U. z 2002 r. Nr 74, poz. 676), http://prawo.sejm.gov.pl/isap.nsf/DocDetails.xsp?id=WDU20020740676 (dostęp: 6.11.2018).

Ustawa z dnia 8 sierpnia 1996 roku o zmianie niektórych ustaw normujących funkcjonowanie gospodarki i administracji publicznej (Dz.U. z 1996 r. Nr 106, poz.496).

Wyrok Trybunału Konstytucyjnego z dnia 24 lutego 2010 roku, sygn. akt K 6/09 (Dz.U. z 2010 r. $\mathrm{Nr} 36$, poz. 204), http://prawo.sejm.gov.pl/isap.nsf/DocDetails.xsp?id=WDU20100360204 (dostęp: 6.11.2018).

Zákon č. 100/1970 Sb., Zákon o služebním poměru př́slušníků Sboru národní bezpečnosti, https:// www.zakonyprolidi.cz/cs/1970-100 (dostęp: 25.10.2018).

Zákon č. 153/1994 Sb., Zákon o zpravodajských službách České republiky, https://www.zakonyprolidi.cz/cs/1994-153 (dostęp: 24.10.2018).

Zákon č. 154/1994 Sb., Zákon o bezpečnostní informační službě, http://www.epi.sk/zzcr/1994-154 (dostęp: 24.10.2018).

Zákon č. 221/1999 Sb., Zákon o vojácích z povolání, https://www.zakonyprolidi.cz/cs/1999-221 (dostęp: 25.10.2018).

Zákon č. 244/1991 Sb., Zákon o Federální bezpečnostní informační službě a o používání zpravodajských prostředků, https://www.zakonyprolidi.cz/cs/1991-244 (dostęp: 24.10.2018).

Zákon č. 33/1995 Sb., Zákon, kterým se mění a doplňuje zákon České národní rady č. 186/1992 Sb., o služebním poměru prríslušníků Policie České republiky, ve znění pozdějších předpisů, 
a zákon č. 100/1970 Sb., o služebním poměru příslušníků Sboru národní bezpečnosti, ve znění pozdějších předpisů, https://www.zakonyprolidi.cz/cs/1995-33 (dostęp: 1.11.2018).

Zákon č. 34/1995 Sb., Zákon, kterým se doplňuje zákon č. 76/1959 Sb., o některých služebních poměrech vojáků, ve znění pozdějších předpisů, https://www.zakonyprolidi.cz/cs/1995-34 (dostęp: 4.11.2018).

Zákon č. 361/2003 Sb., Zákon o služebním poměru příslušníků bezpečnostních sborů, https://www. zakonyprolidi.cz/cs/2003-361 (dostęp: 25.10.2018).

Zákon č. 527/1992 Sb., Zákon České národní rady o Bezpečnostní informační službě České republiky, https://www.zakonyprolidi.cz/cs/1992-527 (dostęp: 24.10.2018).

Zákon o občanských komisích působících v resortech ministerstva vnitra a o změně a doplnění zákona č. 100/1970 Sb., o služebním poměru příslušníků Sboru národní bezpečnosti, ve znění zákonů č. 63/1983 Sb. a č. 74/1990 Sb., https://www.psp.cz/sqw/sbirka.sqw?cz=169\&r=1990 (dostęp: 24.10.2018).

Zarządzenie nr 39 Prezesa Rady Ministrów z dnia 4 lipca 1990 roku w sprawie szczegółowego określenia zadań oraz struktury organizacyjnej Urzędu Ochrony Państwa, [w:] Historyczno-prawna analiza struktur organów bezpieczeństwa państwa w Polsce Ludowej (1944-1990). Zbiór studiów, red. A. Jusupović, R. Leśkiewicz, Warszawa 2013.

\section{Publikacje zwarte}

Antoszewski A., Komparatystyka polityczna, [w:] Encyklopedia politologii, t. 1, red. W. Sokół, M. Żmigrodzki, Kraków 1999.

Błachnia K., Strategie badań empirycznych, [w:] Doktoranci o metodologii nauk ekonomicznych, red. K. Kuciński, Warszawa 2007.

Jusupović A., Leśkiewicz R., Historyczno-prawna analiza struktur organów bezpieczeństwa państwa w Polsce Ludowej (1944-1990), Warszawa 2013.

Karpiński J., Wprowadzenie do metodologii nauk społecznych, Warszawa 2006.

Nowak S., Metodologia badań społecznych, Warszawa 2007.

Porta D. della, Comparative Analisys: Case-oriented Versus Variable-oriented Research, [w:] Approaches and Methodologies in the Social Sciece. A Pluralist Perspective, red. D. della Porta, M. Keating, Cambrige 2008.

Ryza T., Srovnání vývoje zpravodajských služeb v ČR a SR po roce 1989, Praha 2012, https://is.cuni. cz/webapps/zzp/detail/109572/ (dostęp: 1.11.2018).

Zetocha K., Zpravodajské služby v nové demokracii: Česká republika. Disertační práce, Brno 2008, https://is.muni.cz/th/idfhl/Zetocha-Disertace_2008.pdf (dostęp: 23.10.2018).

\section{Artykuły}

Bajer J., Badania porównawcze w politologii. Zagadnienia metodologiczne, „Studia Politicae Universitatis Silensiensis" 8, 2012.

Henzler M., Etaty i budżety stużb specjalnych, „Polityka” 26.10.2009, https://www.polityka.p1/ tygodnikpolityka/kraj/1500287,1, etaty-i-budzety-sluzb specjalnych.read?page=226\&moduleId=4677 (dostęp: 6.11.2018).

Hrbáček J., Výslužné pro bývalé př́slušníky STB, „Radiožurnál” 2003, https://radiozurnal.rozhlas. cz/vysluzne-pro-byvale-prislusniky-stb-6334365 (dostęp: 1.11.2018).

Leśkiewicz R., Od Stużby Bezpieczeństwa do Urzędu Ochrony Państwa, „Dzieje Najnowsze” 48, 2016, z. 1, apcz.umk.pl/czasopisma/index.php/DN/article/download/DN.2016.1.09/9386 (dostęp: 4.11.2018).

Studia nad Autorytaryzmem i Totalitaryzmem 41, nr 1, 2019

(C) for this edition by CNS 
Małecki G., Reforma stużb mundurowych z perspektywy 15 lat, portal-mundurowy.pl, 12.05.2017, http://promilitaria21.home.pl/autoinstalator/joomla/aktualnosci-i-prawo/item/4834-12-vreforma-sluzb-specjalnych-z-perspektywy-15-lat (dostęp: 6.11.2018).

Mečířová L., Náleži výsluhová renta i osobám ve starobním di̊chodu?, Finance.cz, https://www. finance.cz/508953-vysluhova-renta-starobni-duchod/ (dostęp: 25.10.2018).

Miodowicz K., Wszystko zaczęło się w Krakowie, „Przegląd Bezpieczeństwa Wewnętrznego. Wydanie specjalne" 2010, https://www.abw.gov.pl/pl/pbw/publikacje/przeglad-bezpieczenstw-1/569,Prze glad-Bezpieczenstwa-Wewnetrznego-WYDANIE-SPECJALNE.html (dostęp: 5.11.2018).

Pacner K., Poodkrytá tajemství českých tajných služeb za uplynulých dvacet let, IDnes 2010, https:// zpravy.idnes.cz/poodkryta-tajemstvi-ceskych-tajnych-sluzeb-za-uplynulych-dvacet-let-126-/ zpr_archiv.aspx?c=A100506_185201_kavarna_chu (dostęp: 1.11.2018).

Porównanie ustaw dezubekizacyjnych z 2009 i 2016 roku, http://demagog.org.pl/wypowiedzi/porownanie-ustaw-dezubekizacyjnych-z-2009-i-2016-roku/ (dostęp: 6.11.2018).

Reorganizacja służb specjalnych. Spóźniona dekomunizacja w ABW ma wreszcie nastapić?, PAP/ MoRo, Wnet.fm 28.09.2017, https:/wnet.fm/2017/09/28/reorganizacja-sluzb-specjalnychspozniona-dekomunizacja-abw-wreszcie-nastapic/ (dostęp: 7.11.2018).

Skalický J., Před 25 lety zanikla StB, nejmocnějši složka komunistického reżimu, iRozhlas 2015, https://www.irozhlas.cz/zpravy-domov/pred-25-lety-zanikla-stb-nejmocnejsi-slozkakomunistickeho-rezimu_201502010249_krohackova?print=1 (dostęp: 1.11.2018).

Spurný J., BIS a ti druzi, ,Respekt” 13.02.1995, https://www.respekt.cz/tydenik/1995/7/bis-a-ti-druzi (dostęp: 24.10.2018).

Wstẹp redakcji, „Przegląd Bezpieczeństwa Wewnętrznego. Wydanie specjalne. 20-lecie UOP/ ABW", Warszawa 6.04.2010.

Zemanová-Kopecká R., Bývali agenti StB, bud’te v klidu. Odbojáŕi vám na důchody nesáhnou, ParlamentníListy.cz, https://www.parlamentnilisty.cz/zpravy/Byvali-agenti-StB-budte-v-kliduOdbojari-vam-na-duchody-nesahnou-210219 (dostęp: 1.11.2018).

\section{THE ROLE OF FORMER COMMUNIST SECRET OFFICERS \\ IN THE CIVIL INTELLIGENCE AND COUNTERINTELLIGENCE SERVICE IN POLAND AND IN THE CZECH REPUBLIC, 1989-2018}

\section{Summary}

Czech civilian special services after 1989 were built by former officers of the communist services. In Poland and in the Czech Republic, at least at the beginning of the changes, participation in the services of members of the democratic opposition was symbolic. The officers of the communist services in both countries were gradually removed during subsequent reorganizations in the years 1990-2018. In the Czech Republic they have not been completely removed to this day. The Czech authorities deprived them of financial powers acquired in the service of a totalitarian system. The Polish authorities also deprived former security officers of the privileges acquired in service before systemic changes and additionally those already acquired at work for a democratic state. However, the financial severity of both solutions is incomparable due to differences in pension systems of uniformed services between both countries.

Keywords: retirement, Polish Security Service, Czech services.

\section{Witold Graca}

wgraca@wp.pl

Henryk Spustek

hspustek@uni.opole.pl

Studia nad Autorytaryzmem i Totalitaryzmem 41, nr 1, 2019

(C) for this edition by CNS 